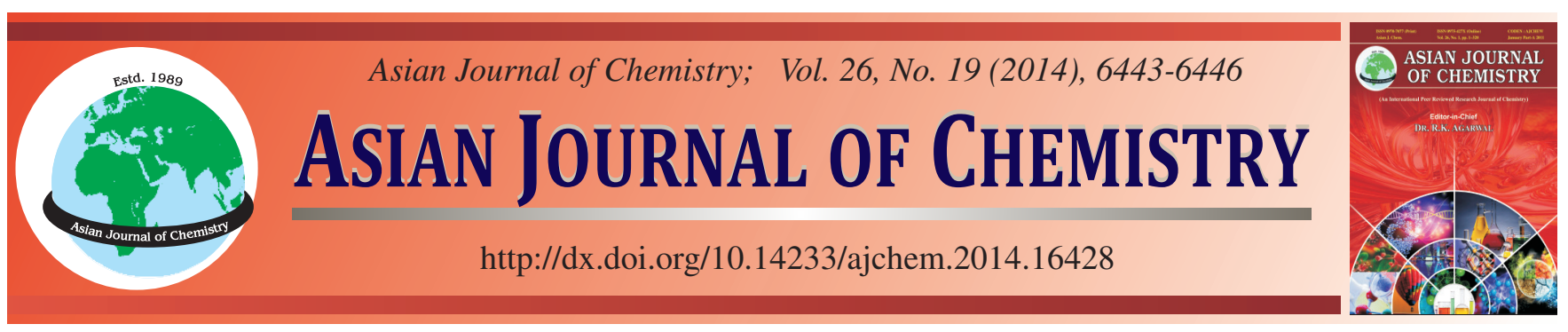

\title{
Synthesis of Manganese Complexes of 4,5-Dihydropyrazoles and Metalation Effect on the Antimicrobial Activity
}

\begin{abstract}
Mamta Ahuja
Department of Chemistry, Government Meera Girls College, Mohan Lal Sukhadia University, Udaipur-313 001, India

Corresponding author: E-mail: mamdeep@ rediffmail.com

1-Acetyl-5-aryl-3-(substituted thienyl)-4,5-dihydropyrazoles and their manganese complexes have been synthesized and characterized on the basis of elemental analysis, magnetic susceptibility, molar conductance, molecular weight determination and spectroscopic data. The IR data indicated that the coordination of the ligands to the manganese (II) ion was through the azomethine nitrogen and carbonyl oxygen. The micro analytical, electronic spectral assignments and magnetic moment suggested an octahedral geometry around the metal ion with 1:2 metal ligand stoichiometry. The complexes exhibited in vitro microbiocidal activity in comparison to ligands.

Keywords: Dihydropyrazoles, Manganese, Complexes, Microbiocidal activity.
\end{abstract}

\section{INTRODUCTION}

Pyrazoles and their derivatives embedded with various functional groups are versatile chelating agents towards metal ions as well as important biological agents and a significant amount of research activity has been directed towards this class. In particular, they are used as, antitumor ${ }^{1}$, anti-antiangeogenic ${ }^{2}$, antibacterial $^{3}$, antifungal ${ }^{4}$, antiviral ${ }^{5}$, antidepressant ${ }^{6}$ and anticonsulvant ${ }^{7,8}$ agents. Some of these compounds have also anti-inflammatory ${ }^{9}$ properties. The recent success of pyrazole COX-2 inhibitor has further highlighted the importance of these heterocyclic rings in medicinal chemistry. The existence of pyrazole core in biological active molecules has stimulated the need for elegant and efficient ways to synthesize these heterocyclic lead. Literature reports reveal that the activity of a ligand can be altered several folds by coordination with suitable metal ion $^{10-12}$, apparently due to the accretion in lipophilicity of the metal chelates ${ }^{13}$. In the present study, we have investigated the interaction of $\mathrm{Mn}^{2+}$ with some newly synthesized pyrazoles. The choice of manganese is promoted by its valence electron configuration, which allow to use it in different and unique ways that typically other elements cannot be used in and its biological significance. Some of the major biological roles of Mn-bound enzymes and proteins are generation of $\mathrm{O}_{2}$ in photosynthesis, essentially involving splitting of $\mathrm{H}_{2} \mathrm{O}$ and destroying the superoxide ion radical (by the Mn enzyme super oxide dismutase) formed as a product of oxidation by $\mathrm{O}_{2}$ in biological system. In order to synthesize some microbiocidal compounds of high potency, these two biologically important moieties were coupled with the resulting metals chelates having enhanced activity.

\section{EXPERIMENTAL}

Physico-chemical measurements: The ${ }^{1} \mathrm{H}$ NMR spectra in $\mathrm{CDCl}_{3}$ were recorded on a Varian EM390 (90 MHz) spectrometer in DMSO $\left(d_{6}\right)$ using TMS as internal reference. IR spectra in nujol mulls on $\mathrm{KBr}$ plates $\left(\lambda_{\max }\right.$ in $\left.\mathrm{cm}^{-1}\right)$ were obtained using a Perkin-Elmer 62, range $4000-200 \mathrm{~cm}^{-1}$ infrared spectrophotometer. The electronic spectra of the complexes were recorded on Beckmann DU-64 spectrophotometer using DMSO as solvent. Conductance values were determined in dry DMSO or DMF at $10^{-3} \mathrm{M}$ concentration on a digital conductivity meter NDC 732. Molecular weight determinations were carried out cryoscopically in dry nitrobenzene. Magnetic susceptibilities were measured on a Sherwood magnetic susceptibility balance, (accuracy $\pm 2 \%$ ) and carbon, hydrogen and nitrogen analyses were performed on an automatic elemental analyzer Carlo Erba Strumentazione model 1106 at RSIC Chandigarh. Manganese was estimated by the atomic absorption spectrophotometer (Varian Techtron, Model AA 120).

Synthesis of ligands: The ligands were synthesized by two methods:

\section{Conventional method}

Synthesis of 3-aryl-1-(substituted thienyl)-2-propen1-one (1): In a solution of $0.01 \mathrm{~mol}$ of 2-acetylthiophene/2acetyl-5-chlorothiophene in methanol was added an aqueous solution of $10^{-3} \mathrm{M}$ sodium hydroxide to adjust the $\mathrm{pH} 10-11$. 
To this solution was added drop wise the corresponding aldehyde $(0.01 \mathrm{~mol})$ with constant stirring at $0-5{ }^{\circ} \mathrm{C}$ which was continued for another $2-4 \mathrm{~h}$ for the ligands $\mathrm{L}_{1}-\mathrm{L}_{3}, 14-18 \mathrm{~h}$ for the ligands $\mathrm{L}_{4}-\mathrm{L}_{6}$. The reaction mixture was then diluted with water and acidified with conc. sulphuric acid. The solid thus separated was washed with water, recrystallized from methanol and dried under reduced pressure.

Microwave method: Equimolar quantity of both reactants was taken in a conical flask with $5 \mathrm{~mL}$ of alcohol. This was kept in microwave for $30 \mathrm{~s}$ on low medium temperature. Thereafter, $5 \mathrm{mg}$ of $\mathrm{NaOH}$ was added to it and was kept in microwave for $2 \mathrm{~min}$. The reaction mixture was then diluted with water and acidified with conc. sulphuric acid. The solid thus separated was washed with water, recrystallized from methanol and dried under reduced pressure.

Synthesis of 1-acetyl-5-aryl-2-(substituted thienyl)-4,5dihydropyrazoles $\left(\mathbf{L}_{1}-\mathbf{L}_{6}\right)$ : A solution of 3-(4-methoxy/3,4dimethoxy / 3,4,5-trimethoxy-1-(2-thienyl)-2-propene-1-one $(0.01 \mathrm{~mol})$ in acetic acid $(25 \mathrm{~mL})$ was refluxed for $10-15 \mathrm{~h}$ with excess of hydrazine hydrate $(1.0 \mathrm{~g}, 0.02 \mathrm{~mol})$. The resulting mixture was cooled and poured onto ice water. The separated solid was washed with water and recrystallized from methanol.

Synthesis of $\mathrm{Mn}^{2+}$ complexes: Manganese chloride $(1.43 \mathrm{~g}, 0.01 \mathrm{~mol})$, dissolved in minimum amount of water ( $5 \mathrm{~mL}$ ), was added to the solution of the corresponding ligand $(0.02 \mathrm{~mol})$ in ethanol $(25 \mathrm{~mL})$ and refluxed for $3 \mathrm{~h}$. The solid thus separated, was filtered, washed with ethanol and dried under vacuum.

\section{RESULTS AND DISCUSSION}

Substituted 3-aryl-1-(substituted thienyl)-2-propen-1-one (1) was synthesized by the condensation of substituted 2acetylthiophenes and substituted aldehydes in methanolic sodium hydroxide solution, which were assigned trans configuration on the basis of the coupling constant $(16 \mathrm{~Hz})$ between two olefinic protons appearing at 7.40 and $8.10 \mathrm{ppm}$ in ${ }^{1} \mathrm{H}$ NMR spectra. The reaction of (1) with hydrazine hydrate in acetic acid gave the ligands $\mathrm{L}_{1}-\mathrm{L}_{6}$ (Fig. 1). Nucleophilic attack is the first step involved in the formation of ligands at the carbonyl group forming unstable $\alpha, \beta$-unsaturated hydrazones which underwent intramolecular rearrangement at the double bond followed by in situ acylation due to the presence of acetic acid as solvent ${ }^{14,15}$. In these ligands, the trans $\mathrm{C}_{4}-\mathrm{H}$ was observed at upfield (3.29-2.53 ppm) relative to its cis analogue (3.16-382 ppm) (Table-1). Further, $\mathrm{J}_{4,5}$-trans was found to be smaller in magnitude (4-6 Hz) as compared to $\mathrm{J}_{4,5}$ - cis $(12 \mathrm{~Hz})$ and was consistent with the literature value ${ }^{16}$. The integrated proton ratio of different groups, as evident from the spectrum of each ligand, was well in agreement with the proposed structure for these ligands.

All the metal complexes obtained were coloured and stable at atmospheric conditions. These were insoluble in most of the common organic solvents (ethanol, acetone, ether and benzene) except in DMSO or DMF. The low conductance values $\left(5-20 \mathrm{ohm}^{-1} \mathrm{~cm}^{2} \mathrm{~mol}^{-1}\right)$ in dry DMSO or DMF indicated their non -electrolytic nature. Manganese(II) generally forms high spin complexes due to the additional stability of half filled

TABLE-1

\begin{tabular}{|c|c|c|c|c|c|c|c|}
\hline \multirow{3}{*}{ Ligand } & \multicolumn{7}{|c|}{$\begin{array}{r}\text { TABLE-1 } \\
\text { PHYSICAL, ANALYTICAL AND }{ }^{1} \mathrm{H} \text { NMR DATA OF 1-ACETYL-5- }\end{array}$} \\
\hline & m.p. & Yield & $m$ & Analytical dat & : observec & lculated) & \\
\hline & $\left({ }^{\circ} \mathrm{C}\right)$ & $(\%)$ & m.t. & $\mathrm{C}$ & $\mathrm{H}$ & $\mathrm{N}$ & H NMR \\
\hline $\mathrm{L}_{1}$ & 95 & 75 & $\mathrm{C}_{16} \mathrm{H}_{16} \mathrm{~N}_{2} \mathrm{O}_{2} \mathrm{~S}$ & $63.5(64.0)$ & $0(5.3)$ & $9.1(9.3)$ & $\begin{array}{l}2.09\left(\mathrm{~s}, 3 \mathrm{H}, \mathrm{COCH}_{3}\right), 3.60(\mathrm{~s}, 3 \mathrm{H}, \\
\text { ArOCH } \\
\text { trans }), 2.53-2.26-3.56\left(\mathrm{dd}, 1 \mathrm{H}, \mathrm{C}_{4}-\mathrm{H}, \mathrm{C}_{4}-\mathrm{H} \text { cis }\right) \\
5.43-5.63\left(\mathrm{dd}, 1 \mathrm{H}, \mathrm{C}_{5}-\mathrm{H}\right), 6.60- \\
7.36(\mathrm{~m}, 7 \mathrm{H}, \mathrm{Ar}-\mathrm{H} \text { and thienyl-H). }\end{array}$ \\
\hline $\mathrm{L}_{2}$ & 160 & 65 & $\mathrm{C}_{17} \mathrm{H}_{18} \mathrm{~N}_{2} \mathrm{O}_{3} \mathrm{~S}$ & $61.9(61.8)$ & (5.4) & $8.5(8.7$ & $\begin{array}{l}2.39\left(\mathrm{~s}, 3 \mathrm{H}, \mathrm{COCH}_{3}\right), 3.83(\mathrm{~s}, 6 \mathrm{H}, \\
\text { ArOCH } \\
\text { trans }), 2.82-3.14\left(\mathrm{dd}, 1 \mathrm{H}, \mathrm{C}_{4}-\mathrm{H}\right. \\
5.60-5.88\left(\mathrm{dd}, 1 \mathrm{H}, \mathrm{C}_{5}-\mathrm{H}\right) 6.95-7.63 \\
(\mathrm{~m}, 6 \mathrm{H}, \mathrm{Ar}-\mathrm{H} \text { and thienyl- } \mathrm{H}) .\end{array}$ \\
\hline $\mathrm{L}_{3}$ & 115 & 70 & $\mathrm{C}_{18} \mathrm{H}_{20} \mathrm{~N}_{2} \mathrm{O}_{4} \mathrm{~S}$ & $59.9(60.0)$ & $5.2(5.5)$ & $7.3(7.8)$ & $\begin{array}{l}2.43\left(\mathrm{~s}, 3 \mathrm{H}, \mathrm{COCH}_{3}\right), 3.80(\mathrm{~s}, 9 \mathrm{H}, \\
\text { ArOCH } \\
\text { trans }), 2.56-2.33-3.63\left(\mathrm{dd}, 1 \mathrm{H}, \mathrm{C}_{4}-\mathrm{H} \text { cis }\right) \\
5.46-5.66\left(\mathrm{dd}, 1 \mathrm{H}, \mathrm{C}_{5}-\mathrm{H}\right) 6.80-7.70 \\
(\mathrm{~m}, 5 \mathrm{H}, \mathrm{Ar}-\mathrm{H} \text { and thienyl- } \mathrm{H}) .\end{array}$ \\
\hline $\mathrm{L}_{4}$ & 110 & 80 & $\mathrm{C}_{16} \mathrm{H}_{15} \mathrm{Cl} \mathrm{N}_{2} \mathrm{O}_{2} \mathrm{~S}$ & $57.1(57.4)$ & $4.7(4.5)$ & $8.2(8.4)$ & $\begin{array}{l}2.16\left(\mathrm{~s}, 3 \mathrm{H}, \mathrm{COCH}_{3}\right), 3.50(\mathrm{~s}, 3 \mathrm{H}, \\
\text { ArOCH } \\
\text { trans }), 2.73-3.35-3.82\left(\mathrm{dd}, 1 \mathrm{H}, 1 \mathrm{H}, \mathrm{C}_{4}-\mathrm{H} \text { cis }\right) \\
5.40-5.63\left(\mathrm{dd}, 1 \mathrm{H}, \mathrm{C}_{5}-\mathrm{H}\right) 6.95-7.76 \\
(\mathrm{~m}, 6 \mathrm{H}, \mathrm{Ar}-\mathrm{H} \text { and thienyl- } \mathrm{H}) .\end{array}$ \\
\hline $\mathrm{L}_{5}$ & 180 & 84 & $\mathrm{C}_{17} \mathrm{H}_{17} \mathrm{Cl} \mathrm{N} \mathrm{O}_{3} \mathrm{~S}$ & $55.8(56.0)$ & $4.3(4.7)$ & 7.9(7.7) & $\begin{array}{l}2.25\left(\mathrm{~s}, 3 \mathrm{H}, \mathrm{COCH}_{3}\right), 3.79(\mathrm{~s}, 6 \mathrm{H}, \\
\left.\mathrm{ArOCH}_{3}\right), 2.85-3.29\left(\mathrm{dd}, 1 \mathrm{H}, \mathrm{C}_{4}-\mathrm{H}\right. \\
\text { trans }), 3.51-3.70\left(\mathrm{dd}, 1 \mathrm{H}, \mathrm{C}_{4}-\mathrm{H} \text { cis }\right) \\
5.65-5.87\left(\mathrm{dd}, 1 \mathrm{H}, \mathrm{C}_{5}-\mathrm{H}\right) 6.82-7.41 \\
(\mathrm{~m}, 5 \mathrm{H}, \mathrm{Ar}-\mathrm{H} \text { and thienyl-H). }\end{array}$ \\
\hline $\mathrm{L}_{6}$ & 123 & 82 & $\mathrm{C}_{16} \mathrm{H}_{16} \mathrm{~N}_{2} \mathrm{O}_{2} \mathrm{~S}$ & $54.9(54.7)$ & $4.7(4.8)$ & $7.3(7.1)$ & $\begin{array}{l}2.36\left(\mathrm{~s}, 3 \mathrm{H}, \mathrm{COCH}_{3}\right), 3.69(\mathrm{~s}, 9 \mathrm{H}, \\
\left.\mathrm{ArOCH}_{3}\right), 2.53-2.83\left(\mathrm{dd}, 1 \mathrm{H}, \mathrm{C}_{4}-\mathrm{H}\right. \\
\text { trans }), 3.16-3.43\left(\mathrm{dd}, 1 \mathrm{H}, \mathrm{C}_{4}-\mathrm{H} \text { cis }\right) \\
5.63-5.86\left(\mathrm{dd}, 1 \mathrm{H}, \mathrm{C}_{5}-\mathrm{H}\right) 6.94-7.45 \\
(\mathrm{~m}, 4 \mathrm{H}, \mathrm{Ar}-\mathrm{H} \text { and thienyl-H). }\end{array}$ \\
\hline
\end{tabular}




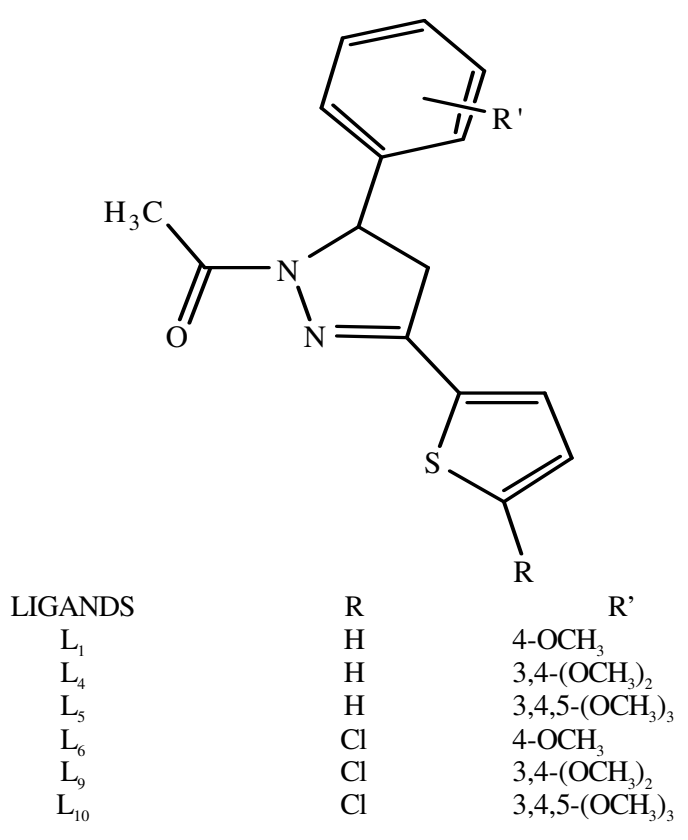

Fig. 1. Structure of ligands

$3 d$ subshell. High spin manganese(II) has a ${ }^{6} \mathrm{~A}_{1}$ ground state in the octahedral configuration. This is the only spin sextet of the configuration and departures from the spin only value of the magnetic moment due to spin-orbit mixing of higher states and low symmetry components of the crystal field are expected to be negligible. The magnetic moments are found to be very close to the spin only value of 5.92 BM and are independent of temperature and stereochemistry. The observed effective magnetic moments of the manganese(II) complexes of ligands $\left(\mathrm{L}_{1}-\mathrm{L}_{6}\right)\left(5.95-6.12\right.$ B.M. at $\left.25^{\circ} \mathrm{C}\right)$ were consistent with high spin manganese(II).

Electronic spectra: The electronic spectra of manganese(II) complexes differ from those of other transition metal ion complexes because of the presence of large number of bands of lower intensity and variable width. Four electronic spectral bands were to be observed in the complexes under study (Table-1). These bands near 19000, 22000, 25000 and 28000 $\mathrm{cm}^{-1}$ were assigned to ${ }^{6} \mathrm{~A}_{0 \mathrm{~g}} \rightarrow{ }^{4} \mathrm{~T}_{1 \mathrm{~g}}(\mathrm{G}),{ }^{6} \mathrm{~A}_{1 \mathrm{~g}} \rightarrow{ }^{4} \mathrm{~T}_{2 \mathrm{~g}}(\mathrm{G}),{ }^{6} \mathrm{~A}_{1 \mathrm{~g}} \rightarrow$ ${ }^{4} \mathrm{E}_{\mathrm{g}}(\mathrm{G})$ and ${ }^{6} \mathrm{~A}_{1 \mathrm{~g}} \rightarrow{ }^{4} \mathrm{~T}_{2 \mathrm{~g}}(\mathrm{D})$ transitions respectively, indicating the octahedral environment (Fig. 2) around manganese(II) ${ }^{17,18}$.

Infrared spectra: The infrared spectra of the complexes showed a hypsochromic shifts in the $\mathrm{v}(\mathrm{C}=\mathrm{N})$ mode from 16101580 to $1590-1555 \mathrm{~cm}^{-1}$. The $v(\mathrm{~N}-\mathrm{N})$ manifested a positive shift of $10-20 \mathrm{~cm}^{-1}$. The negative shift in $\mathrm{v}(\mathrm{C}=\mathrm{N})$ and positive shift in $v(\mathrm{~N}-\mathrm{N})$ mode were indicative of coordination of the nitrogen of azomethine group of pyrazolines to the metal ion.

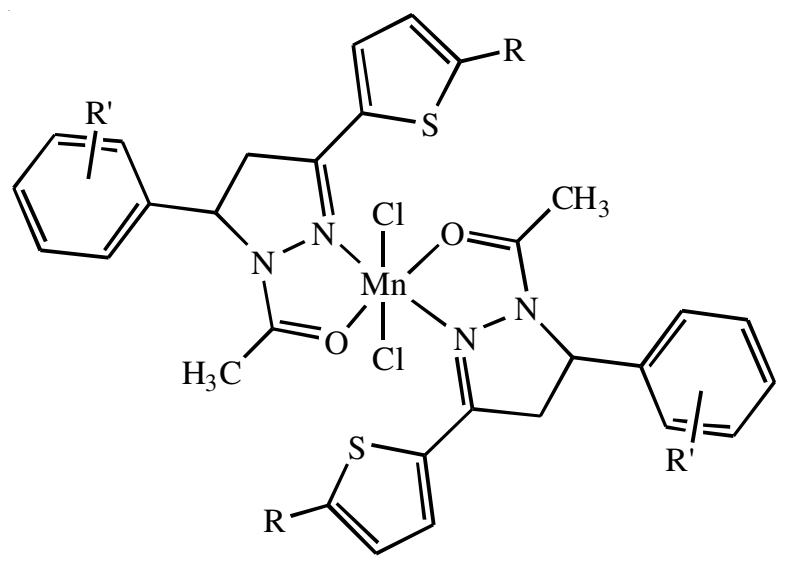

Fig. 2. Structure of complexes

The participation of the carbonyl oxygen in bonding was revealed by a downward spectral shift in the $v(\mathrm{C}=\mathrm{O})$ mode from $1620-1660 \mathrm{~cm}^{-1}$ in the spectra of ligands to $1600-1640$ $\mathrm{cm}^{-1}$ in the spectral of complexes. This thiophene ring stretching vibration remained essentially unaltered in the spectra of metal complexes. This strongly suggested that the sulphur of thiophene ring was not involved in coordination. The new absorption frequencies appearing in the far infrared region at 490-505, 405-420 and 290-295 $\mathrm{cm}^{-1}$ in the spectra of metal complexes were attributed to $\mathrm{M}-\mathrm{O}, \mathrm{M}-\mathrm{N}$ and $\mathrm{M}-\mathrm{Cl}$ stretching vibration, respectively ${ }^{19,20}$. Thus, the IR studies establishment that the coordination of the ligands to the manganese(II) ion was through the azomethine nitrogen and carbonyl oxygen. The magnetic and electronic spectral assignments (Table-2) suggested an octahedral geometry around the metal ion with 1:2 metal ligands stoichiometry.

Investigation of antimicrobial activity: The synthesized ligands and their complexes were evaluated for their antimicrobial activity against four phytopathogenic fungi of economic significance, viz., Alternaria alternata, Colletotrichum capsicum, Fusarium oxysporum and Rhizoctoia solani and two bacteria, viz., Gram-positive Bacillus subtilis and Gram-negative Escherichia coli. Two fold serial dilution technique ${ }^{21}$ was employed for the in vitro growth inhibitory studies against the test organism. The concentration at which complete growth inhibition observed, was taken as the minimum inhibitory concentration (MIC) value expressed in $\mu \mathrm{g} \mathrm{mL}^{-1}$. The bar plots (MIC value $v / s$ compounds) showed the comparative activity pattern of different ligands and their complexes. The substituted 2-pyrazolines, viz., 1-acetyl-5-aryl-2-(substituted thienyl)-2pyrazolines $\left(\mathrm{L}_{1}-\mathrm{L}_{6}\right)$ exhibited promising activity against the entire test organisms. The compounds could effectively control the growth of organisms at concentration ranging from $>100$

TABLE-2

MAGNETIC AND ELECTRONIC SPECTRAL DATA OF MANGANESE(II) COMPLEXES OF 1-ACETYL-5-ARYL-3-(SUBSTITUTED THIENYL)-2-PYRAZOLINES

\begin{tabular}{cccccc}
\hline Complex & ${ }^{6} \mathrm{~A}_{1 \mathrm{~g}}{ }^{4} \mathrm{~T}_{1 \mathrm{~g}}(\mathrm{G})\left(\mathrm{cm}^{-1}\right)$ & ${ }^{6} \mathrm{~A}_{1 \mathrm{~g}} \rightarrow{ }^{4} \mathrm{~T}_{2 \mathrm{~g}}(\mathrm{G})\left(\mathrm{cm}^{-1}\right)$ & ${ }^{6} \mathrm{~A}_{1 \mathrm{~g}} \rightarrow{ }^{4} \mathrm{E}_{\mathrm{g}}(\mathrm{G})\left(\mathrm{cm}^{-1}\right)$ & ${ }^{6} \mathrm{~A}_{1 \mathrm{~g}} \rightarrow{ }^{4} \mathrm{~T}_{2 \mathrm{~g}}(\mathrm{D})\left(\mathrm{cm}^{-1}\right)$ & $\mu_{\text {eff }}(\mathrm{B} . \mathrm{M})$. \\
\hline$\left[\mathrm{Mn}\left(\mathrm{L}_{1}\right)_{2} \mathrm{Cl}_{2}\right]$ & 19345 & 22390 & 25225 & 28411 & 5.95 \\
{$\left[\mathrm{Mn}\left(\mathrm{L}_{2}\right)_{2} \mathrm{Cl}_{2}\right]$} & 19390 & 22460 & 25300 & 28422 & 6.12 \\
{$\left[\mathrm{Mn}\left(\mathrm{L}_{3}\right)_{2} \mathrm{Cl}_{2}\right]$} & 19240 & 22540 & 25315 & 28432 & 6.05 \\
{$\left[\mathrm{Mn}\left(\mathrm{L}_{4}\right)_{2} \mathrm{Cl}_{2}\right]$} & 19260 & 22670 & 25345 & 28511 & 6.00 \\
{$\left[\mathrm{Mn}\left(\mathrm{L}_{5}\right)_{2} \mathrm{Cl}_{2}\right]$} & 19510 & 22495 & 25280 & 28425 & 6.12 \\
{$\left[\mathrm{Mn}\left(\mathrm{L}_{6}\right)_{2} \mathrm{Cl}_{2}\right]$} & 19315 & 22654 & 25315 & 28440 & 6.10 \\
\hline
\end{tabular}


to $3.15 \mu \mathrm{g} \mathrm{mL} \mathrm{L}^{-1}$. Among the fungi, Alternaria alternata was the most affected organism against which the compounds had the least MIC values $\left(12.5 \mu \mathrm{g} \mathrm{mL}^{-1}\right)$. The mode of action of 2pyrazolines may involve the inhibition of certain specific biochemical reactions like formation of RNA, ATP, translation and transcription, as a consequence of which the normal cellular processes of growth and divisions are affected ${ }^{22}$. The presence of different functional groups on nucleus and side chain length have marked effect on the magnitude of biological activities. The introduction of methoxy group at 5-position of pyrazolines ring increased the biological activity of these compounds $^{23}$. A perusal of Fig. 3 revealed that among the variously substituted 2-pyrazolines, the compounds with 3,4,5trimethoxy phenyl group at position-5 and thienyl group at position -3 of pyrazoline ring $\left(\mathrm{L}_{3}\right.$ and $\left.\mathrm{L}_{6}\right)$ were the most active $\left(\mathrm{MIC}=12.5 \mu \mathrm{g} \mathrm{mL}^{-1}\right.$ ) against Alternaria alternata and Escherichia coli followed by 3,4-dimethoxyphenyl substituted 2pyrazolines $\left(\mathrm{L}_{2}\right.$ and $\left.\mathrm{L}_{4}\right)$ which exhibits the MIC values up to $25 \mu \mathrm{g} \mathrm{mL}^{-1}$ and 4-methoxy substituted pyrazolines were the least active $\left(\mathrm{MIC}=50 \mu \mathrm{g} \mathrm{mL}{ }^{-1}\right)$. Following structure activity order could be drawn from the activity data:

$$
3,4,5-\left(\mathrm{OCH}_{3}\right)_{3}>3,4-\left(\mathrm{OCH}_{3}\right)_{2}>4-\mathrm{OCH}_{3}
$$

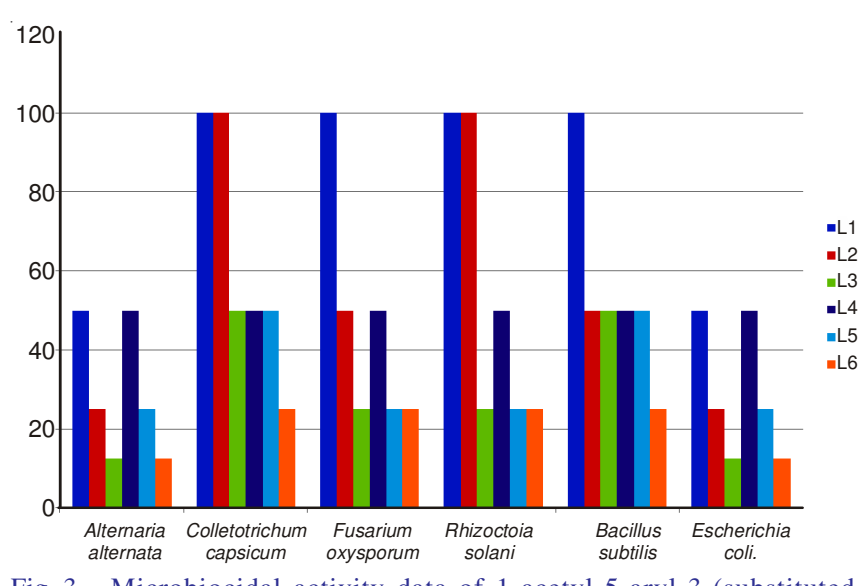

Fig. 3. Microbiocidal activity data of 1-acetyl-5-aryl-3-(substituted thienyl)-4,5-dihydropyrazoles

The pyrazolines having 5-chloro-2-thienyl moiety at position-3 $\left(\mathrm{L}_{4}-\mathrm{L}_{6}\right)$ were even more potential antimicrobial agents than the compounds with unsubstituted thienyl group. The effect of substituents on the activity pattern of these compounds may be due to the alteration in lipophillicity of parent group. The presence of some specific group also makes the molecules recognizable by the biological receptors making them suitable and preferentially active. In addition, coordination of the bioactive ligands with suitable metal ions significantly altered their activity pattern ${ }^{24}$. In the present investigation, the complexes of 1-acetyl-5-aryl-3(substituted thienyl)2-pyrazolines with $\mathrm{Mn}(\mathrm{II})$ exhibited promising microbiocidal activity against the test organisms (Fig. 4). The ligand as well as the complexes of 3,4,5-trimethoxy substituent's were the most active compounds against the fungi and bacteria.

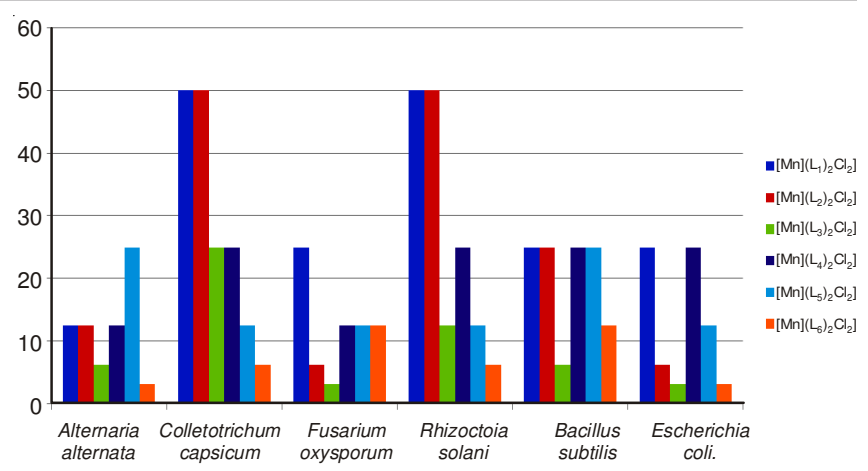

Fig. 4. Microbiocidal activity data of manganese complexes of 1-acetyl5-aryl-3-(substituted thienyl)-4,5-dihydropyrazoles

\section{REFERENCES}

1. P.-C. Lv, H.-Q. Li, J. Sun, Y. Zhou and H.-L. Zhu, Bioorg. Med. Chem., 18, 4606 (2010).

2. M.S. Christodoulou, S. Liekens, K.M. Kasiotis and S.A. Haroutounian, Bioorg. Med. Chem., 18, 4338 (2010).

3. B.F. Abdel-Wahab, H.A. Abdel-Aziz and E.M. Ahmed, Eur. J. Med. Chem., 44, 2632 (2009).

4. D. Zampieri, M.G. Mamolo, E. Laurini, G. Scialino, E. Banfi and L. Vio, Bioorg. Med. Chem., 16, 4516 (2008).

5. O.L. El-Sabbagh, M.M. Baraka, S.M. Ibrahim, P. Pannecouque, G. Andrei, R. Snoeck, J. Balzarini and A.A. Rashad, Eur. J. Med. Chem., 44, 3746 (2009).

6. M.S. Karthikeyan, B.S. Holla and N.S. Kumari, Eur. J. Med. Chem., 42, 30 (2007).

7. B.F. Abdel-Wahab, H.A. Abdel-Aziz and E.M. Ahmed, Eur. J. Med. Chem., 44, 2632 (2009).

8. M. Abdel-Aziz, A. El-Din, G. Abuo-Rahma and A. A. Hassan, Eur. J. Med. Chem., 44, 3480 (2009).

9. N. Gokhan -Kelekc, S. Yabanog lu, E. Ku Peli, U. Salgm, O. Ozgen, G. Ucar, E. Yesilada, E. Kendi, Y. Yesiladaf and A.A. Bilgin, Bioorg. Med. Chem., 15, 5775 (2007).

10. R. Malhotra, M.S. Malik, J.P. Singh and K.S. Dhindsa, J. Inorg. Biochem., 45, 269 (1992).

11. R. Malhotra, J.P. Singh, M. Dudeja and K.S. Dhindsa, J. Inorg. Biochem., 46, 119 (1992).

12. P. Lumme, H. Elo and J. Janne, Inorg. Chim. Acta, 92, 241 (1984).

13. R. Malhotra, S. Kumar and K.S. Dhindsa, Indian J. Chem., 32A, 457, (1993).

14. N.K. Sangwan, B.S. Verma and K.S. Dhindsa, J. Prakt. Chem., 330, 137 (1988).

15. N.R. El-Rayyes and N.A. Al-Awadi, Synthesis, 1028 (1985).

16. N.K. Sangwan, B.S. Verma and K.S. Dhindsa, Indian J. Chem., 25B, 672 (1986).

17. R.C. Sharma and R.K. Parashar, J. Inorg. Biochem., 32, 163 (1988).

18. L.J. Heidt, G.F. Koster and A.M. Johnson, J. Am. Chem. Soc., 80, 6471 (1958).

19. R. Nagar, J. Inorg. Biochem., 37, 193 (1989).

20. K. Nakamoto, Infrared and Raman Spectra of Inorganic and Coordination Compound, Wiley Interscience, New York (1978).

21. G.C. Donald and A.R. Williams, A Laboratory Manual, Medical Encyclopedia Inc (1955).

22. V.F. Portyanko, A.P. Myagchenko and V.I. Dulova, Fiziol. Biokhim. Kul't. Rast., 14, 371 (1982).

23. M. Windholz, The Merck Index, Merck \& Co., New Jersey, edn 9 (1976).

24. H. Theorell, T. Yonetani, B. Sjoberg, O. Theander, A.A. Lindberg, G. Jansen, B. Lamm and B. Samuelsson, Acta Chem. Scand., 23, 255 (1969). 